\title{
Front Matter: Volume 9032
}

, "Front Matter: Volume 9032," Proc. SPIE 9032, Biophotonics-Riga 2013, 903201 (18 November 2013); doi: 10.1117/12.2052537

SPIE Event: 1st International Conference "Biophotonics Riga 2013", 2013, Riga, SPIE. Latvia 


\title{
PROGRESS IN BIOMEDICAL OPTICS AND IMAGING
}

\section{Biophotonics-Riga 2013}

\author{
Janis Spigulis \\ Ilona Kuzmina \\ Editors
}

26-31 August 2013

Riga, Latvia

Organized by

University of Latvia (Latvia)

Sponsored by

EC FP7 project "Fotonika - LV" (Latvia)

The Optical Society

European Photonics Industry Consortium

Cooperating Organization and Publisher

SPIE

\section{Volume 9032}


The papers included in this volume were part of the technical conference cited on the cover and title page. Papers were selected and subject to review by the editors and conference program committee. Some conference presentations may not be available for publication. The papers published in these proceedings reflect the work and thoughts of the authors and are published herein as submitted. The publisher is not responsible for the validity of the information or for any outcomes resulting from reliance thereon.

Please use the following format to cite material from this book:

Author(s), "Title of Paper," in Biophotonics-Riga 2013, edited by Janis Spigulis, Ilona Kuzmina, Proceedings of SPIE Vol. 9032 (SPIE, Bellingham, WA, 2013) Article CID Number.

ISSN: 1605-7422

ISBN: 9780819499806

Published by

SPIE

P.O. Box 10, Bellingham, Washington 98227-0010 USA

Telephone +1 3606763290 (Pacific Time) · Fax +1 3606471445

SPIE.org

Copyright @ 2013 , Society of Photo-Optical Instrumentation Engineers.

Copying of material in this book for internal or personal use, or for the internal or personal use of specific clients, beyond the fair use provisions granted by the U.S. Copyright Law is authorized by SPIE subject to payment of copying fees. The Transactional Reporting Service base fee for this volume is $\$ 18.00$ per article (or portion thereof), which should be paid directly to the Copyright Clearance Center (CCC), 222 Rosewood Drive, Danvers, MA 01923. Payment may also be made electronically through CCC Online at copyright.com. Other copying for republication, resale, advertising or promotion, or any form of systematic or multiple reproduction of any material in this book is prohibited except with permission in writing from the publisher. The CCC fee code is $1605-7422 / 13 / \$ 18.00$.

Printed in the United States of America.

Publication of record for individual papers is online in the SPIE Digital Library.

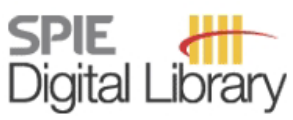

SPIEDigitalLibrary.org

Paper Numbering: Proceedings of SPIE follow an e-First publication model, with papers published first online and then in print and on CD-ROM. Papers are published as they are submitted and meet publication criteria. A unique, consistent, permanent citation identifier (CID) number is assigned to each article at the time of the first publication. Utilization of CIDs allows articles to be fully citable as soon as they are published online, and connects the same identifier to all online, print, and electronic versions of the publication. SPIE uses a six-digit CID article numbering system in which:

- The first four digits correspond to the SPIE volume number.

- The last two digits indicate publication order within the volume using a Base 36 numbering

system employing both numerals and letters. These two-number sets start with 00, 01, 02, 03, 04,

05, 06, 07, 08, 09, 0A, OB ... 0Z, followed by 10-1Z, 20-2Z, etc.

The CID Number appears on each page of the manuscript. The complete citation is used on the first page, and an abbreviated version on subsequent pages. Numbers in the index correspond to the last two digits of the six-digit CID Number. 


\section{Contents}

vii Conference Committees
ix Introduction

BIOPHOTONICS-RIGA 2013

903202 Assessment of hemoglobin dynamics in traumatic bruises using temperature depth profiling [9032-24]

L. Vidovič, M. Milanič, B. Majaron, Jožef Stefan Institute (Slovenia)

903203 Application of colour magnification technique for revealing skin microcirculation changes under regional anaesthetic input [9032-9]

U. Rubins, J. Spigulis, Univ. of Latvia (Latvia); A. Miscuks, Hospital of Traumatology and Orthopaedics (Latvia)

903204 Application of principal component analysis to multispectral imaging data for evaluation of pigmented skin lesions [9032-3]

D. Jakovels, I. Lihacova, I. Kuzmina, J. Spigulis, Univ. of Latvia (Latvia)

903205 Modelling the appearance of chromatic environment using hyperspectral imaging [9032-21]

S. Fomins, Institute of Solid State Physics (Latvia); M. Ozolinsh, Institute of Solid State Physics (Latvia) and Univ. of Latvia (Latvia)

903206 Fabrication and characterization of a 3-D non-homogeneous tissue-like mouse phantom for optical imaging [9032-30]

S. Avtzi, A. Zacharopoulos, S. Psycharakis, G. Zacharakis, Foundation for Research and Technology-Hellas (Greece)

903207 Multimodal device for assessment of skin malformations [9032-2]

A. Bekina, Univ. of Latvia (Latvia); V. Garancis, Telemedica SIA (Latvia); U. Rubins,

J. Spigulis, Univ. of Latvia (Latvia); L. Valeine, Beauty Clinic Altera Victoria (Latvia);

A. Berzina, The Clinic of Laser Plastics (Latvia)

903208 Evaluation of a multispectral diffuse optical spectroscopy device for assessment of cardiometabolic risk related alterations of body composition [9032-25]

Z. Marcinkevics, K. Volceka, L. Ozolina-Moll, J. Zaharans, Univ. of Latvia (Latvia)

903209 Fluorescence spectroscopy of gastrointestinal tumors: in vitro studies and in vivo clinical applications [9032-5]

L. Angelova, E. Borisova, A. Zhelyazkova, Institute of Electronics (Bulgaria);

M. Keremedchiev, B. Vladimirov, Univ. Hospital Queen Jiovanna-ISUL (Bulgaria);

L. Avramov, Institute of Electronics (Bulgaria) 
9032 OA Excitation-emission matrices measurements of human cutaneous lesions: tool for fluorescence origin [9032-6]

A. Zhelyazkova, E. Borisova, L. Angelova, Institute of Electronics (Bulgaria); E. Pavlova, M. Keremedchiev, Univ. Hospital Queen Jiovanna-ISUL (Bulgaria)

9032 OB Fluorescence lifetime spectroscopy: potential for in-vivo estimation of skin fluorophores changes after low power laser treatment [9032-27]

I. Ferulova, A. Lihachev, J. Spigulis, Univ. of Latvia (Latvia)

9032 OC Blue and UV fluorescence of biological fluids and carbon nanodots [9032-10]

A. Kuznetsov, A. Frorip, AS Ldiamon (Estonia); M. Ots-Rosenberg, A. Sünter, Univ. of Tartu (Estonia)

9032 OD Fluorescence spectroscopy for estimation of anticancer drug sonodestruction in vitro [9032-19]

A. Lihachev, D. Jakovels, I. Ferulova, J. Spigulis, Univ. of Latvia (Latvia); M. Tamosiunas, S. Satkauskas, Vytautas Magnus Univ. (Lithuania); C. W. Lo, W. S. Chen, National Taiwan Univ. (Taiwan)

9032 OE Assessment of efficiencies of electroporation and sonoporation methods by using fluorescence RGB imaging method [9032-4]

D. Jakovels, A. Lihachev, J. Spigulis, Univ. of Latvia (Latvia); S. Satkauskas, M. Tamosiunas, Vytautas Magnus Univ. (Lithuania); C. W. Lo, W. S. Chen, National Taiwan Univ. (Taiwan)

9032 OF Change dynamics of RBC morphology after injection glucose for diabetes by diffraction phase microscope [9032-22]

N. A. Talaykova, A. L. Kalyanov, V. V. Lychagov, Saratov State Univ. (Russian Federation); V. P. Ryabukho, Saratov State Univ. (Russian Federation) and Institute of Precision Mechanics and Control (Russian Federation); L. I. Malinova, FGE Saratov SII Cardiology Rosmedtechnologii (Russian Federation)

9032 OG Correlation mapping method of OCT for visualization blood vessels in brain [9032-31] O. A. Izotova, A. L. Kalyanov, V. V. Lychagov, O. V. Semyachkina-Glushkovskaya, Saratov State Univ. (Russian Federation)

$9032 \mathrm{OH} \quad$ Express control of plants general state by using the new generation of the instrumental tools [9032-26]

K. E. Shavanova, M. V. Taran, O. A. Marchenko, N. F. Starodub, National Univ. of Life and Environmental Sciences of Ukraine (Ukraine)

9032 Ol Biocidal effects of silver and zinc oxide nanoparticles on the bioluminescent bacteria [9032-20]

M. V. Taran, N. F. Starodub, National Univ. of Life and Environmental Sciences of Ukraine (Ukraine); A. M. Katsev, Crimean State Medical Univ. (Ukraine); M. Guidotti, Institute of Molecular Sciences and Technology, CNR (Italy); V. D. Khranovskyy, Linköping Univ. (Sweden); A. A. Babanin, Crimean State Medical Univ. (Ukraine); M. D. Melnychuk, National Univ. of Life and Environmental Sciences of Ukraine (Ukraine)

9032 0J Spatial photometry of scattered radiation by biological objects [9032-15]

N. V. Bezuglaya, M. A. Bezuglyi, National Technical Univ. of Ukraine (Ukraine) 
9032 OK Muscle tissue saturation in humans studied with two non-invasive optical techniques: a comparative study [9032-41]

A. Shaharin, Lund Univ. (Sweden); E. Krite Svanberg, Lund Univ. (Sweden) and Skåne Univ. Hospital (Sweden); I. Ellerström, Skåne Univ. Hospital (Sweden); A. A. Subash, D. Khoptyar, S. Andersson-Engels, Lund Univ. (Sweden); J. Åkeson, Skåne Univ. Hospital (Sweden)

$9032 \mathrm{OL} \quad$ Assessment of conduit artery vasomotion using photoplethysmography [9032-33] K. Kanders, A. Grabovskis, Z. Marcinkevics, J. I. Aivars, Univ. of Latvia (Latvia)

9032 OM Development of a novel combined fluorescence and reflectance spectroscopy system for guiding high-grade glioma resections: confirmation of capability in lab experiments [9032-8]

M. Mousavi, H. Xie, Z. Xie, M. Brydegaard, J. Axelsson, S. Andersson-Engels, Lund Univ. (Sweden)

9032 ON Applicability of diffusion approximation in analysis of diffuse reflectance spectra from healthy human skin [9032-34]

P. Naglič, Univ. of Ljubljana (Slovenia); L. Vidovič, M. Milanič, Jožef Stefan Institute (Slovenia); L. L. Randeberg, Norwegian Univ. of Science and Technology (Norway); B. Majaron, Jožef Stefan Institute (Slovenia)

$903200 \quad$ Water detection in skin by dual-band photodiodes [9032-43]

I. Saknite, E. Kviesis, J. Spigulis, Univ. of Latvia (Latvia)

9032 OP Methodology for assessment of low level laser therapy (LLL) irradiation parameters in muscle inflammation treatment [9032-28]

M. Mantineo, J. P. Pinheiro, A. M. Morgado, Univ. de Coimbra (Portugal)

$90320 Q \quad$ Reliability and validity of optoelectronic method for biophotonical measurements [9032-14] K. Karpienko, M. S. Wróbel, Gdansk Univ. of Technology (Poland); R. Urniaż, Medical Univ. of Lublin (Poland)

9032 OR Novel combined fluorescence/reflectance spectroscopy system for guiding brain tumor resections: hardware considerations [9032-35]

Z. Xie, H. Xie, M. Mousavi, M. Brydegaard, J. Axelsson, S. Andersson-Engels, Lund Univ. (Sweden)

9032 OS Elastic light single-scattering spectroscopy for detection of dysplastic tissues [9032-23] M. Canpolat, T. Denkçeken, A. Akman, E. Alpsoy, R. Tuncer, M. Akyüz, M. Baykara, S. Yücel, I. Başsorgun, M. A. Çiftçioğlu, G. A. Gökhan, E. Gürer, E. Peştereli, Ş. Karaveli, Akdeniz Üniv. (Turkey)

9032 OT $\quad \mathrm{TiO}_{2}$ optical sensor for amino acid detection [9032-7]

A. Tereshchenko, R. Viter, I. Konup, V. Ivanitsa, S. Geveliuk, Y. Ishkov, V. Smyntyna, Odessa I.I. Mechnikov National Univ. (Ukraine)

9032 OU Dedicated power supply subsystem for ultra-low noise preamplifiers and biophotonic sensors [9032-12]

Ł. Surażyński, P. Wierzba, A. Zienkiewicz, Gdańsk Univ. of Technology (Poland)

9032 OV Ellipsoidal reflectors in biomedical diagnostic [9032-13]

M. A. Bezuglyi, N. V. Bezuglaya, National Technical Univ. of Ukraine (Ukraine) 
9032 OW Near real time, accurate, and sensitive microbiological safety monitoring using an all-fibre spectroscopic fluorescence system [9032-42]

F. Vanholsbeeck, S. Swift, M. Cheng, E. Bogomolny, The Univ. of Auckland (New Zealand)

$90320 X \quad$ Immune biosensors based on the SPR and TIRE: efficiency of their application for bacteria determination (Invited Paper) [9032-16]

N. F. Starodub, J. Ogorodniichuk, National Univ. of Life and Environmental Sciences of Ukraine (Ukraine); T. Lebedeva, P. Shpylovyy, V.M. Glushkov Institute of Cybernetics

(Ukraine)

9032 OY New ways to develop biosensors towards addressing practical problems [9032-17]

N. F. Starodub, National Univ. of Life and Environmental Sciences of Ukraine (Ukraine)

$90320 Z$ Effect of colloidal metals on the induced chlorophyll fluorescence at the different lupin state [9032-37]

R. V. Son'ko, N. F. Starodub, National Univ. of Life and Environmental Sciences of Ukraine (Ukraine); V. V. Trach, Institute of Plant Physiology and Genetics (Ukraine); K. G. Lopat'ko, National Univ. of Life and Environmental Sciences of Ukraine (Ukraine)

903210 Comparison of the efficiency control of mycotoxins by some optical immune biosensors [9032-40]

N. F. Slyshyk, N. F. Starodub, National Univ. of Life and Environmental Sciences of Ukraine (Ukraine)

Author Index 


\title{
Conference Committees
}

\author{
Conference Chairs \\ Janis Spigulis, University of Latvia (Latvia) \\ Ilona Kuzmina, University of Latvia (Latvia) \\ Scientific Committee \\ Janis Spigulis, University of Latvia (Latvia) \\ Janis Alnis, University of Latvia (Latvia) \\ Aigars Ekers, University of Latvia (Latvia) \\ Ricardas Rotomskis, Vilnius University (Lithuania) \\ Alexander Priezzhev, Lomonosov Moscow State University (Russian \\ Federation) \\ Göran Salerud, Linköping University (Sweden) \\ Katarina Svanberg, Lund University (Sweden) \\ Arnolds Ubelis, University of Latvia (Latvia) \\ Roman Viter, Odessa National I.I. Mechnikov University (Ukraine) \\ Local Organizing Committee \\ Janis Spigulis, University of Latvia (Latvia) \\ Ilona Kuzmina, University of Latvia (Latvia) \\ Ojars Balcers, University of Latvia (Latvia) \\ Dina Berzina, University of Latvia (Latvia) \\ Dainis Jakovels, University of Latvia (Latvia) \\ Natalija Lesina, University of Latvia (Latvia) \\ Uldis Rubins, University of Latvia (Latvia) \\ Inga Shirante, University of Latvia (Latvia) \\ Inga Saknite, University of Latvia (Latvia) \\ Session Chairs
}

1 Challenging Problems of Biophotonics I

Göran Salerud, Linköping University (Sweden)

2 Challenging Problems of Biophotonics II

Ricardas Rotomskis, Vilnius University (Lithuania)

3 Biophotonic Medical Sensors I

Stefan Andersson-Engels, Lund University (Sweden)

4 Biophotonic Medical Sensors II

Roman Viter, Odessa National I.I. Mechnikov University (Ukraine) 
$5 \quad$ Biophotonic Medical Sensors III

Saulius Bagdonas, Vilnius University (Lithuania)

6 Biophotonic Environmental Sensors I

Alexander Priezzhev, Lomonosov Moscow State University (Russian Federation)

7 Biophotonic Environmental Sensors II

David Sampson, The University of Western Australia (Australia) 


\section{Introduction}

The first International Conference "Biophotonics-Riga 2013" (BPR13) and the related training course were held in Riga on 26-31 August 2013. The conference was organized by Biophotonics Laboratory, Institute of Atomic Physics and Spectroscopy (University of Latvia) with support of the European Commission FP7 project "FotonikaLV", SPIE, The Optical Society (OSA) and European Photonics Industry Consortium.

Three key topics were discussed: (i) Challenging Problems in Biophotonics, (ii) Biophotonic Medical Sensors, and (iii) Biophotonic Environmental Sensors. Biophotonics experts from several European countries, Russia, Australia, and New Zealand presented their recent achievements in this emerging research and technology area. In total, 17 countries were represented.

We would thank all authors, participants, and sponsors for their contribution to the success of the Biophotonics-Riga Conference.

Janis Spigulis llona Kuzmina 